\title{
Apparatus for studying electro-physical properties of materials at low temperatures under external magnetic fields
}

\author{
O.M.Bovda, V.V.Derevyanko, T.V.Sukhareva, V.A.Finkel \\ National Science Center "Kharkiv Institute of Physics and Technology", \\ 1 Akademicheskaya Str., 61108 Kharkiv, Ukraine
}

Received March 14, 2014

\begin{abstract}
The object of the work is development and experimental realization of the apparatus for measuring electro-physical properties of materials at temperatures 15-273 K in external magnetic field $\mathbf{H}_{\text {ext }}$; in the apparatus, a gas heat engine (cryo-generator) has been used for obtaining low temperatures, and a system of permanent magnets has been applied for producing magnetic fields with magnetization force up to several kOe. Actually, the apparatus consists of two large blocks: a stationary setup for producing low temperatures using the cryo-generator (Leybold), and a detachable setup for creating magnetic fields using a system of permanent magnets pairs made from high-coercive $\mathrm{Nd}_{2} \mathrm{Fe}_{14} \mathrm{~B}$ alloy. A system for collecting and treating the data obtained has been developed. For testing the apparatus, comparative measurements of electrical resistivity temperature dependence for $\mathrm{MgB}_{2}$ superconductor have been carried out both in zero magnetic field and under $H_{e x t}=2 \mathrm{kOe}$.
\end{abstract}

Цель работы - разработка и опытная реализация установки для проведения измерений электрофизических свойств материалов при температурах 15-273 К во внешнем магнитном поле $\mathbf{H}_{\text {ext }}$, в которой для получения низких температур применяется газовая тепловая машина (криогенератор), а для создания магнитных полей напряженностью до нескольких $\mathrm{kOe}$ используется система постоянных магнитов. Установка фактически состоит из двух крупных блоков: стационарного устройства для создания низких температур с помощью криогенератора (Leybold) и съемного устройства для создания магнитных полей на основе системы из пар постоянных магнитов из высоко коэрцитивного сплава $\mathrm{Nd}_{2} \mathrm{Fe}_{14}$ B. Разработана система сбора и обработки полученных данных. Для тестирования установки проведены сравнительные измерения температурной зависимости электросопротивления сверхпроводника $\mathrm{MgB}_{2}$ в нулевом магнитном поле и при $H_{e x t}=2 \mathrm{kOe}$.

Установка для проведення досліджень електрофізичних властивостей матеріалів при низьких температурах у зовнішніх магнітних полях. О.М.Бовда, В.В.Дерев'янко, Т.В.Сухарева, В.О.Фінкель.

Мета роботи - розробка і дослідна реалізація установки для проведення вимірювань електрофізичних властивостей матеріалів при температурах $15-273 \mathrm{~K}$ у зовнішньому магнітному полі $\mathbf{H}_{\text {ext }}$, в якій для отримання низьких температур застосовується газова теплова машина (кріогенератор), для створення магнітних полів напруженістю до декількох $\mathrm{kOe}$ використовується система постійних магнітів. Установка фактично складається 3 двох крупних блоків: стаціонарного пристрою для створення низьких температур за допомогою кріогенератора (Leybold) і знімного пристрою для утворення магнітних полів на основі системи 3 пар постійних магнітів з висококоерцитівного сплаву $\mathrm{Nd}_{2} \mathrm{Fe}_{14}$ B. Розроблено систему збору і обробки одержаних даних. Для тестування установки проведено порівняльні вимірювання температурної залежності електроопіру надпровідника $\mathrm{MgB}_{2}$ у нульовому магнітному полі і при $H_{e x t}=2 \mathrm{kOe}$. 


\section{Introduction}

Studying the galvano-magnetic effects, namely, magneto-resistance, volt ampere characteristics (CVCs) in the external magnetic field $H_{\text {ext }}$, critical currents of superconductors, etc. - at low temperatures is of great importance in various fields of modern physics (solid state physics, superconductivity, magnetism, semiconductor physics, etc.). Such investigations were carried out during more than a hundred years, and by now, numerous experimental apparatuses of different complexity have been created for measurements in the wide range of temperatures $T$ and external magnetization force $H_{\text {ext }}$ (see, for example, some works of last years [1-3]).

In spite of multiplicity of the modern apparatus designs for galvano-magnetic measurements at low temperatures, as well as working ranges for temperature and magnetic field variations, practically in all cases the cryogen liquids (nitrogen, helium, rarer - oxygen, argon, etc.) are applied, and for production of magnetic fields solenoids with winding from superconductor or normal metal are used.

The aim of the work is development and creation of the experimental apparatus for measurements of electrical resistivity, critical currents in superconductors, and voltampere characteristics in external magnetic field $H_{\text {ext }}$, and other galvano-magnetic effects; in the apparatus, in contrast to known measuring circuits for low temperature production, the cryo-generator is applied, which is a gas heat engine; and for creating magnetic fields, a system of permanent magnets is used.

\section{Apparatus arrangement}

Before to describe the peculiarities of the apparatus design we note the following two points:

1. As the main part of the apparatus which provided the temperature range $\sim 15-$ $300 \mathrm{~K}$, the cryo-generator RGD-210 (Leybold) has been used.

2. For creating the magnetic field source - a system of permanent magnets - several sets of cylinders made from high coercive $\mathrm{Nd}_{2} \mathrm{Fe}_{14} \mathrm{~B}$ alloy pressed powder have been used [5,6]. The working range of the magnetic fields was $0-\sim 2000$ Oe. Note that application of permanent magnets with higher residual magnetization values $B_{r}$ and coercive force $H_{c}$ allows increasing the maximum values $H_{\text {ext }}$.

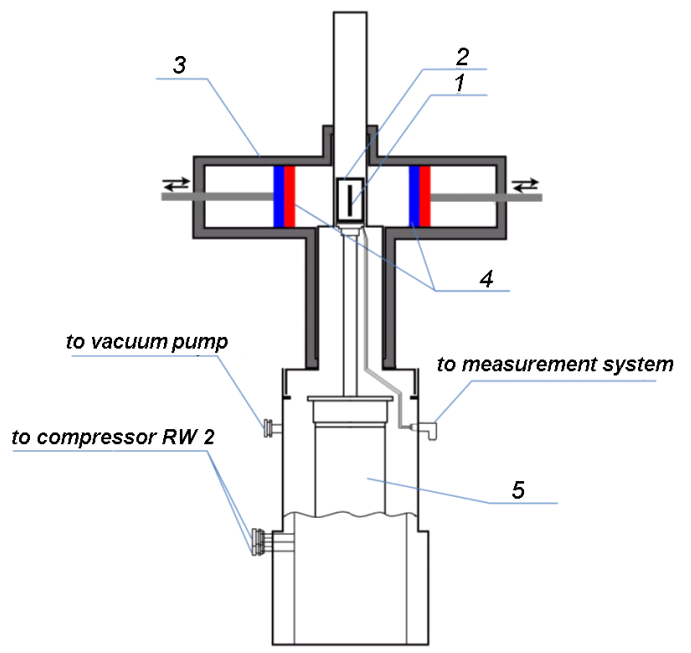

Fig. 1. Arrangement of the apparatus for measuring electrical resistivity and CVCs in magnetic field and other galvano-magnetic effects: 1 - sample; 2 - measuring cell; 3 - holder of permanent magnets; 4 - magnets; 5 - cryo-generator RGD-210 (Leybold).

The arrangement of the apparatus for measurements of electrical resistance and CVCs in magnetic field as well as other galvanomagnetic effects is shown in Fig. 1.

It is seen from Fig. 1 that the apparatus consists actually of two large blocks: a stationary setup for producing low temperatures 5 [cryo-generator RGD-210 (Leybold)], and a removable setup 3 for creating the magnetic fields using a system of permanent magnet pairs 4 made from $\mathrm{Nd}_{2} \mathrm{Fe}_{14} \mathrm{~B}$ high coercive alloy. The sample studied 1 together with a standard Pt resistance thermometer is positioned within the measuring cell 2 filled by gaseous helium before work beginning in order to increase heat exchange.

The magnetization force $H_{\text {ext }}$ of the external magnetic field influencing on the sample 1 is determined by parameters of applied set of "discs" from permanent magnets (there are several different sets for the apparatus) and by the distance $L$ between the magnets symmetrically positioned relative to the sample. The $H_{\text {ext }}$ was measured using magnetic induction instrument SH1-8 with accuracy $\pm 1.5 \%$. [The calibration curve for one of the sets, i.e. the dependence of the magnetization force on the distance $H(L)$ is shown in Fig. 2].

Note that the internal diameter of the removable part of the apparatus (the holder of the magnet system 3) is only a little larger than the diameter of cylindrical sur- 


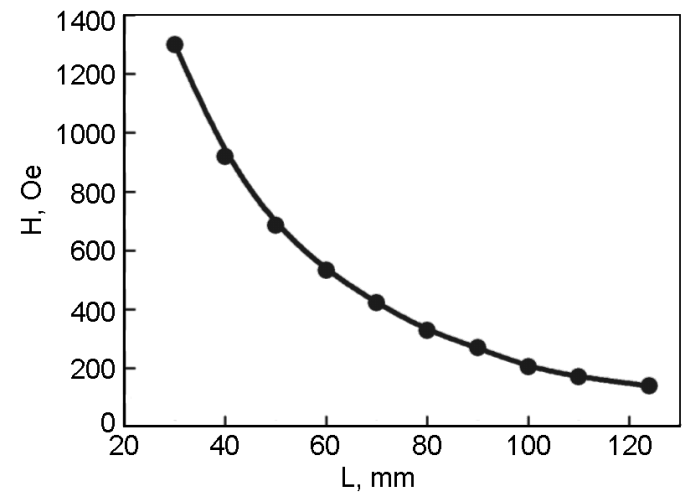

Fig. 2. Magnetization force value versus the distance, $H(L)$.

face of the cryo-generator working part 5 . The design of the magnet system holder provides the constancy of the condition: the normal $(N)$ to the flat sample 1 surface and the magnetization force vector $H_{\text {ext }}$ of external magnetic field produced by the permanent magnet system 4 - are positioned in the same plane. The special limb allows setting the angle between $N$ and $H_{\text {ext }}$ vectors with accuracy $\sim 1 \mathrm{deg}$ [in the present work all measurements were carried out in transversal magnetic fields $\left.\left(I \perp H_{e x t}\right)\right]$.

\section{Measurements, collection and treatment of the data}

To provide the possibility for measurements of electrical and magnetic properties in the external magnetic field $H_{\text {ext }}$ in automatic regime, the special soft-ware complex was developed for collection and treatment of the data obtained. The complex is the essential part of the apparatus. The modern high-tech instruments have been used for the complex creation.

In order to provide high efficiency of the work, all the instruments had the same standard (GIP); the following instruments were applied for measurements of electrical resistance temperature dependences: 34410 A, 34420 A, 34780 A.

During the measurements the data were registered by the computer using the interface USB/GPIB $82257 \mathrm{~B}$. The information about the experiment was visualized in the monitor both in text and plot representations and remained for following treatment.

\section{Testing the apparatus}

For testing the apparatus functional possibilities, measurements of electrical resistivity $(\rho)$ temperature dependences for $\mathrm{MgB}_{2}$ superconductor in the temperature range
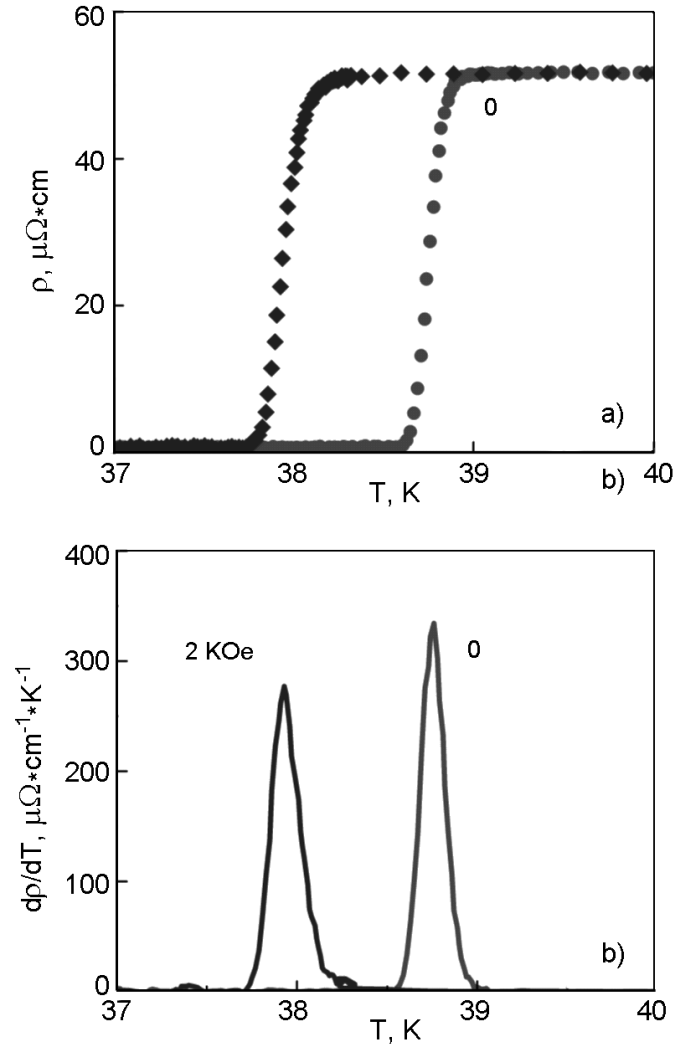

Fig. 3. Temperature dependences of (a) electrical resistivity, $\rho$, and (b) $d \rho / d T$ derivative for $\mathrm{MgB}_{2}$ superconductor.

15-273 K have been carried out both under zero magnetic field and at $H_{\text {ext }}=2000 \mathrm{Oe}$. As it is known, the critical temperature for $\mathrm{MgB}_{2} T_{c} \sim 40 \mathrm{~K}$ [7].

In Fig. 3, the temperature dependences of electrical resistivity $\rho$ and $d \rho / d T$ values are shown. As it is seen, the results of testing the $\rho$ measurements for $\mathrm{MgB}_{2}$ indicate a noticeable shift of critical temperature $\Delta T_{c^{\sim}}$ $1 \mathrm{~K}$ under relatively weak magnetic field. ( $T_{c}$ values were determined by the position of $d \rho / d T$ maximum on the temperature axis). Similar $\Delta T_{c}$ values were obtained in other works (see, for example [8,9]).

\section{Conclusions}

The main result of the work is development and creation of the apparatus for studying electrical and magnetic properties of materials at low temperatures under external magnetic fields with magnetization force up to $2 \mathrm{kOe}$. Principal distinctions of the apparatus in comparison to numerous devices for similar purpose are the following: firstly, it is application of cryo-generator for production of low temperatures; 
secondly, application of high-coercive permanent magnets for creating moderately strong magnetic fields. Application of the cryo-generator instead of systems using cryogen liquids, as well as permanent magnets instead of solenoids substantially simplifies experiments on studying the material properties under special conditions.

Application of modern measuring instruments, methods and means of computing technique provides high efficiency of collection and treatment of the experimental data.

High exploitation qualities of the apparatus for studying electro-physical properties of materials at low temperatures under external magnetic fields are supported by the test experiments on magnetic field influence on behavior of electrical resistivity near the superconductive transition temperature.

\section{References}

1. A.Altinkok, K.Kilic, M.Olutas, A.Kilic, $J$. Supercond, Novel Magnetism, 27, 651 (2014).

2. A.Altinkok, K.Kilic, M.Olutas, A.Kilic, J. Supercond. Novel Magnetism, 26, 3085 (2013).

3. Suchitra Rajput, Sujeet Chaudhary, J. Supercond.d Novel Magnetism, 26, 2375 (2013).

4. V.V.Derevyanko, T.V.Sukhareva, V.A.Finkel, Phys. Solid State, 48, 1455 (2006).

5. O.M.Bovda, V.O.Bovda, L.V.Onischenko et al., Functional Materials, 20, 203 (2013).

6. O.M.Bovda, V.O.Bovda, V.V.Chebotarev et al., Functional Materials, 15, 589 (2008).

7. J.Nagamatsu, N.Nakagawa, T.Muranaka et al., Nature, 410, 63 (2001).

8. S.Patnaik, L.D.Cooley, A.Gurevich et al., Supercond. Sci. Technol., 14, 315 (2001).

9. S.L.Bud'ko, G.Lapertot, C.Petrovic et al., Phys. Rev. Lett., 86, 1877 (2001). 